DOI: 10.14720/aas.2016.107.2.07

Agrovoc descriptors: Triticum aestivum, wheats, cereals, drought stress, genotypes, drought resistance, drought tolerance, statistical methods

Agris category code: U10, U30/F30

\title{
In vitro application of integrated selection index for screening drought tolerant genotypes in common wheat
}

\author{
Ezatollah FARSHADFAR ${ }^{1}$, Reza AMIRI $^{2}$
}

Received Janury 16, 2016; accepted March 21, 2016.

Delo je prispelo 16. januarja 2016, sprejeto 21. marca 2016.

\begin{abstract}
This experiment was conducted on 20 wheat genotypes during 2010-2011 growing season at the Razi University, Kermanshah, Iran. A completely randomized design with six replications was used for callus induction and a $20 \times 2$ factorial experiment with three replications was used for response of genotypes to in vitro drought stress. ANOVA exhibited highly significant differences among the genotypes for callus growth rate, relative fresh mass growth, relative growth rate, callus water content, percent of callus chlorosis and proline content under stress condition (15\% PEG). PCA showed that the integrated selection index was correlated with callus growth index, relative fresh mass growth, relative growth rate and proline content indicating that these screening techniques can be useful for selecting drought tolerant genotypes. Screening drought tolerant genotypes and in vitro indicators of drought tolerance using mean rank, standard deviation of ranks and biplot analysis, discriminated genotypes 2, 18 and 10 as the most drought tolerant. Therefore they are recommended to be used as parents for genetic analysis, gene mapping and improvement of drought tolerance.
\end{abstract}

Key words: biplot analysis, mature embryo culture, drought stress, physiological indicators, principal component analysis, Triticum aestivum

\section{IZVLEČEK}

\section{IN VITRO UPORABA INTEGRALNEGA SELEKCIJSKEGA INDEKSA ZA IZBOR NA SUŠO ODPORNIH GENOTIPOV NAVADNE PŠENICE}

Poskus je bil izveden na 20 genotipih navadne pšenice $\mathrm{v}$ rastni sezoni 2010-2011 na Razi University, Kermanshah, Iran. Popolno naključni načrt poskusa $s$ šestimi ponovitvami je bil uporabljen za indukcijo kalusa, z $20 \times 2$ faktorskim poskusom $\mathrm{s}$ tremi ponovitvami pa se je ugotavljal odziv genotipov pšenice na sušni stres $\mathrm{v}$ razmerah in vitro. ANOVA je pokazala visoko značilne razlike med genotipi $\mathrm{v}$ rasti kalusa, prirastku sveže mase, hitrosti njene prirasti, vsebnosti vode $\mathrm{v}$ kalusu, odstotku kloroze kalusa in $\mathrm{v}$ vsebnosti prolina $\mathrm{v}$ stresnih razmerah (15\% PEG). PCA analiza je pokazala, da je integralni selekcijski indeks koreliral z indeksom rasti kalusa, s prirastkom sveže mase, hitrostjo njene prirasti in vsebnostjo prolina, kar kaže, da so te presevne metode uporabne za izbor na sušo odpornih genotipov. Pri izboru na sušo odpornih genotipov s kazalniki ospornosti na sušo $\mathrm{v}$ in vitro poskusu kot osnovnim merilom, sta standardna deviacija vrednosti analiziranih znakov in "biplot" analiza izločili genotipe 2, 18 in 10 kot najbolj odporne na sušo. Zaradi tega so bili ti priporočeni za uporabo kot starševske rastline za genske analize, gensko mapiranje in izboljševanje odpornosti na sušo.

Ključne besede: biplot analiza, kultura zrelega embrija, sušni stres, fiziološki indikatorji, analiza glavnih komponent, Triticum aestivum

\section{INTRODUCTION}

Common wheat (Triticum aestivum L.) as one of the most widely adapted and strategic crop, plays an important role in food security and poverty alleviation and has an important role in economy

Razi University, Department of Agronomy and Plant Breeding, Faculty of Sciences and Agricultural Engineering, 6715685438, Kermanshah, Iran. *Corresponding author email: e_farshadfar@yahoo.com

2 Razi University, Department of Agronomy and Plant Breeding, Faculty of Sciences and Agricultural Engineering, 6715685438, Kermanshah, Iran. 
(Khan et al., 2011). It is nutritious, easy to store and transport and can be processed into various types of food. Wheat production will have to be doubled to 1200 MT by the 2025 in order to meet increasing world demands and future needs (Vasil, 2003). But, wheat production is restricted by drought exposed areas and this loss led to considerable economic and social problems due to its great importance on human nutrition (Ilker et al., 2011).

Drought is one of the major causes of crop loss worldwide commonly reduces average yield for many crop plants by more than $50 \%$ (Bayoumi et al., 2008; Pan et al., 2002). Reducing the losses of crop production due to drought stress is a major area of concern to ensure food security (Anjum et al., 2011). So, it is an urgent need to develop new genotypes with traits that could not only tolerate serious drought stress at various stages of growth but can also produce higher grain yield under drought stress conditions (Amiri et al., 2013). The ability of improving wheat genotypes that are able to maximum use of existing water and drought tolerant is one of the main aims of increasing grain yield potential in semi-arid and dry areas (Ghasemali et al., 2011). Therefore, developing high-yielding wheat genotypes under drought conditions in arid and semi-arid regions is an important aim of breeding programs (Leilah and AL-Khateeb, 2005). But success has been limited by inadequate screening techniques. Therefore, wheat breeders are always looking for new means to improve grain yield and other agronomic traits (Khakwani et al., 2011). The adoption of new criteria such as Integrated Selection Index (ISI) through a physiological approach may help in achieving some of the aims to increase wheat yield. A physiological approach would be the most attractive way to develop new varieties (Araus et al., 2008). Understanding the physiological processes associated with yield's trait relationships in modern wheat genotypes is essential to further increase grain yield and improve management strategies (Yea et al., 2011). Measurements of different physiological processes of plant response to drought is an important information on the reactions of the plant intended to remove or to reduce the harmful effects of water deficit in the soil or plant tissues.

An another view, breeding for drought tolerance by selecting solely for grain yield is difficult due to its low heritability under drought conditions (Farshadfar et al., 2012). Much attention is shifted towards crop improvement biotechnological technique. Tissue culture techniques are becoming increasingly popular as an alternative means of plant vegetative propagation, mass production of chemicals, and genetic engineering (Shah et al., 2009). Adoption of novel techniques such as exploitation of In vitro tissue culture may facilitate to increase food production and nutritional values of crops (Mahmood et al., 2012). In vitro selection technique has been used to improve abiotic environmental stresses such as cold hardiness, salt tolerance and drought tolerance (Zair et al., 2003; Bajji et al., 2004; Gawande et al., 2005). In vitro culture of plant cells and tissues such as mature embryos and immature embryos has attracted considerable interest over recent years because it provides a means to study plant physiological and genetic processes and offers a potential to improve cultivars by increasing genetic variability and are considered to be an important complement to classical plant breeding methods (Binott et al., 2009; Sorkheh et al., 2011).

The main aims of the present study were therefore to (1) screen bread wheat genotypes for drought tolerance under in vitro conditions and (2) introduce an integrated selection index for callus physiological indicators of drought tolerance.

\section{MATERIALS AND METHODS}

Twenty bread wheat genotypes including a cultivar and 19 landraces of Kermanshah province, listed in Table 1, were provided from Seed and Plant Improvement Institute of Karaj, Iran. A Completely Randomized Design (CRD) with six replications was used for callus induction and a
$20 \times 2$ factorial experiment based on CRD design with three replications was carried out for response of genotypes to in vitro drought stress during 20102011 growing season at the Campus of Agriculture and Natural Resources, Razi University, Kermanshah, Iran (latitude $34^{\circ} 21^{\prime}$ North, 
longitude $47^{\circ} 9^{\prime}$ East, altitude $1319 \mathrm{~m}$ above sea level). The genotypes were exposed to $15 \%$ concentration of PEG 6000 (Merck, Germany) for 14 days, beside $0 \%$ concentration as control. The growing morphogenic calli derived from mature embryos were also exposed to Murashige and Skoog (1962) medium without PEG and medium containing $15 \%$ concentration of PEG. Spikes were harvested from main tillers at the physiological maturity stage of growing cycle. Seeds of them were rinsed with water then were surface-sterilized in $70 \%(\mathrm{v} / \mathrm{v})$ ethanol for $5 \mathrm{~min}$, rinsed thrice with sterile distilled water, incubated further in commercial bleach $(5 \%$ sodium hypochlorite) for 10-15 min and rinsed thrice with sterile distilled water again. In order to easy separating of embryos, seeds were incubated in sterile distilled water for $30 \mathrm{~min}$. All the operations and inoculation were performed under strict aseptic conditions in a laminar airflow cabinet. The surface-sterilized seeds were incubated at $33{ }^{\circ} \mathrm{C}$ for $2 \mathrm{~h}$ in sterile distilled water for imbibitions to occur. The mature embryos were easily separated from the endosperm in imbibed seeds and placed scutellum up on MS medium supplemented with $30 \mathrm{~g} . \mathrm{l}^{-1}$ sucrose and was adjusted to $\mathrm{pH}=5.7$, solidified with 8 g. $\mathrm{l}^{-1}$ agar and 2.5 mg. $\mathrm{l}^{-1}$ 2,4dichlorophenoxy acetic acid (2,4-D) (Merck, Germany). The medium was autoclaved at $121^{\circ} \mathrm{C}$ for $20 \mathrm{~min}$ and incubated at $25^{\circ} \mathrm{C}$ for 28 days in growth chamber and in the darkness. Callus was maintained by sub-culturing every 21-28 days on the same MS medium. In drought stress conditions the cultures were kept in an incubator without any light. The following callus characteristics were measured under drought stress conditions:

Table 1: Codes and names of genotypes used in presented study

\begin{tabular}{clcl}
\hline Code & Genotype & Code & Genotype \\
\hline & & & \\
1 & WC -5047 & 11 & WC -47636 \\
& & & \\
2 & WC -4530 & 12 & WC -4584 \\
3 & WC -4780 & 13 & WC $-46697-11$ \\
4 & WC -4566 & 14 & WC -4823 \\
5 & WC -47360 & 15 & Pishtaz \\
6 & WC -4640 & 16 & WC -47341 \\
7 & WC -47456 & 17 & WC -47379 \\
8 & WC -47628 & 18 & WC -4931 \\
9 & WC -47367 & 19 & WC -47381 \\
10 & WC -47399 & 20 & WC -5053 \\
\hline
\end{tabular}

\subsection{Callus Growth Rate (CGR)}

CGR (mm.day ${ }^{-1}$ ) of cultured embryos on MS medium were measured at 7, 14, 21 and 28 days, respectively after transferring calli to medium. CGR was calculated using the following formulas (Compton, 1994):

$$
\begin{aligned}
& \mathrm{CGR}_{1}=\mathrm{d}_{7} / 7, \mathrm{CGR}_{2}=\mathrm{d}_{14} / 7, \mathrm{CGR}_{3}=\mathrm{d}_{21} / 7, \\
& \mathrm{CGR}_{4}=\mathrm{d}_{28} / 7 \\
& \mathrm{CGR}=\left(\mathrm{CGR}_{1}+\mathrm{CGR}_{2}+\mathrm{CGR}_{3}+\mathrm{CGR}_{4}\right) / 4
\end{aligned}
$$

Where $d_{7}, d_{14}, d_{21}, d_{28}$ were diameter of callus in days $7,14,21$ and 28, respectively. Diameter of callus was calculated as:

Diameter of callus $(\mathrm{DC})=\sqrt{\text { length } \times \text { width }}$

\subsection{Relative Fresh Mass Growth (RFWG)}

$\operatorname{RFMG}=\left[\left(\mathrm{M}_{2}-\mathrm{M}_{1}\right)\right] / \mathrm{M}_{1}$

Where $M_{1}$ and $M_{2}$ are the initial mass of callus before and after four weeks, respectively (Chen et al. 2006).

\subsection{Relative Growth Rate (RGR)}

$\mathrm{RGR}=\left[\mathrm{LnM}_{2}-\mathrm{LnM}_{1}\right] / \mathrm{GP}$

Where $M_{1}$ and $M_{2}$ are the initial and final mass of callus and GP is the growth period, respectively (Birsin and Ozgen, 2004). The time interval between two consecutive measurements was 21 days.

Acta agriculturae Slovenica, 107 - 2, september 2016 


\subsection{Callus Growth Index (CGI)}

CGI or increasing value of callus fresh mass was calculated as:

$\mathrm{CGI}=\left(\mathrm{M}_{1}-\mathrm{M}_{0}\right) / \mathrm{M}_{0}$

Where $\mathrm{M}_{0}$ is the mass of callus before treatment and $\mathrm{M}_{1}$ the final mass of callus after two weeks of treatment (Abdelsamad et al., 2007). Callus growth index was calculated for two levels of PEG ( 0 and $15 \%)$ and the average of two levels was used for calculation.

\subsection{Relative tolerance (Rt \%)}

Percentage of Rt was calculated for each genotype using the following formula (Abdelsamad et al., 2007):

Rt $\%=$ (value under stress / value under nonstress) $\times 100$

\subsection{Reduction Percentage (RP)}

$\mathrm{RP}$ was calculated for the both stress $(15 \%)$ and non-stress level (0) using the following formula (Abdelsamad et al., 2007):

$\mathrm{RP}=($ value under $15 \%$ stress level - value at $0 \%$ stress level)

\subsection{Callus Water Content (CWC)}

Callus samples of known fresh mass were dried in an oven set at $70{ }^{\circ} \mathrm{C}$ for $24 \mathrm{~h}$ and RWC was calculated by following formula (Errabi et al., 2006):

$\mathrm{RWC}=[(\mathrm{FM}-\mathrm{DM}) / \mathrm{DM}] \times 100$

Where, FM and DM are the callus fresh and dry mass, respectively.

\subsection{Percentage of Callus Chlorosis (PCC)}

PCC (\%) was determined visually as percentage of necrotic callus, 16 days after moving callus to the PEG containing medium.

\subsection{Proline Content (PC)}

Extraction and estimation of free proline content was done according to the procedure described by Errabi et al. (2006).

\subsection{Integrated Selection Index (ISI)}

Based on statistical analysis of studied traits and the following three formulas ISI was calculated (Farshadfar, 2012):

(1) $S_{i j}=\left(X_{i j}-\mu_{j}\right) / \sigma_{j}$

(2) $\mathrm{MP}_{\mathrm{ij}}=\left(\mathrm{S}_{\mathrm{ij}} \mathrm{d}+\mathrm{S}_{\mathrm{ij}} \mathrm{w}\right) / 2$

(3) $\mathrm{ISI}_{\mathrm{i}}=\mathrm{b}_{1} \mathrm{MP}_{\mathrm{i} 1}+\mathrm{b}_{2} \mathrm{MP}_{\mathrm{i} 2}+\ldots+\mathrm{b}_{\mathrm{j}} \mathrm{MP}_{\mathrm{ij}}$

Where $S_{i j}=$ standardized physiologic value of trait $\mathrm{j}$ ( $\mathrm{j}=1$ to 9 , i.e. CGR, RFMG, RGR, CGI, Rt \%, RP, CWC, PCC and PC) in genotype i under nonstress (w) and stress (d) conditions, $X_{\mathrm{ij}}=$ callus characteristics value of genotype $i$ on trait $j, \mu_{j}=$ mean value of trait $j$ in all genotypes, $\sigma_{j}=$ the standard deviation of trait $\mathrm{j}, \mathrm{MP}_{\mathrm{ij}}=$ the mean productivity of trait $j$ on genotype $i, b_{j}$ the mass value of trait $j, b_{j}$ was populated from the average contribution to factor 1 and ISI = integrated selection index. Formula (1) standardizes the value of different traits to the same unit of measure; formula (2) evaluates the appearance of genotypes for each trait; and formula (3) integrates the appearance of genotypes for all traits.

\subsection{Statistical analysis}

Analysis of variance, mean comparison using Duncan's Multiple Range Test and biplot analysis using principal component analysis (PCA), based on the rank correlation matrix were performed by MSTAT-C, SPSS ver. 16 and STATISTICA version 8. Standard Deviation of Ranks (SDR) was measured as:

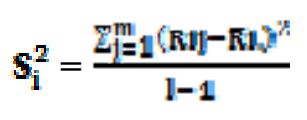

Where $\mathrm{R}_{\mathrm{ij}}$ is the rank of in vitro drought tolerance indicator and $\overline{\mathrm{R}} \mathrm{i}$ is the mean rank across all in vitro drought tolerance indicators for the ith genotype and $\mathrm{SDR}=\left(\mathrm{S}_{\mathrm{l}}^{2}\right)^{0.5}$.

Rank sum $(\mathrm{RS})=$ Rank mean $(\overline{\mathrm{R}} \mathrm{i})+$ Standard Deviation of Rank (SDR) (Farshadfar and Elyasi, 2012). 


\section{RESULTS}

\subsection{Analysis of variance and mean comparisons}

Highly significant differences were observed among the genotypes for CGR, RFMG and RGR (Table 2). Analysis of variance for callus growth rate (CGR), relative fresh mass growth (RFMG), relative growth rate $(\mathrm{RGR})$, callus water content (CWC), percentage of callus chlorosis (PCC) and proline content $(\mathrm{PC})$ indicated highly significant differences among the genotypes in the stress conditions (15\%) (Table 3). The analysis of variance also showed significant effect of the $15 \%$ concentration of PEG on the indicators of drought tolerance in comparison with untreated control. Moreover, the genotype $\times$ drought interaction for $\mathrm{CWC}$ and $\mathrm{PC}$ was significant. The results indicated that CGR, RFMG, RGR and CWC decreased in the stress condition (15\% PEG level) as compared with non-stress condition (0 \% PEG Level) but, PC and PCC were increased in $15 \%$ PEG level as compared with $0 \%$ PEG level (Table 4).

The results obtained from Table 5 exhibited that the highest amount of RFMG, RGR, CWC, PC and
ISI belonged to genotypes number 2, while genotype number 13 showed the highest amount of CGR. The lowest amount of CGR, RGR, and PC was attributed to genotypes number 4,11 and 20, respectively. Moreover, the lowest amount of RFMG, CWC and ISI were belonging to genotypes number 17. An integrated selection index (ISI) for drought resistance was proposed and used to identify drought resistant wheat genotypes. In ISI, nine traits including callus growth rate (CGR), relative fresh mass growth (RFMG), relative growth rate (RGR), callus growth index (CGI), relative tolerance $(\mathrm{Rt} \%)$, reduction percentage (RP), callus water content (CWC), percentage of callus chlorosis (PCC) and proline content (PC) were chosen as the most relevant factors related to drought resistance, as determined by statistical analysis. In our study, genotypes number 17, 4 and 20 displayed the lowest and genotypes number 2, 1 and 10 the highest values for ISI. The highest and the lowest PCC were related to genotypes 17 and 2 , respectively.

Table 2: Analysis of variance for callus induction traits

\begin{tabular}{lcccc}
\hline \multirow{2}{*}{ S.O.V } & \multirow{2}{*}{ Df } & \multicolumn{3}{c}{ Mean Square } \\
\cline { 3 - 5 } & 19 & CGR & RFMG & RGR \\
\hline Genotype & 100 & $0.003^{* *}$ & $0.094^{* *}$ & $0.004^{* *}$ \\
Error & - & 0.00018 & 0.003 & 0.00018 \\
\hline CV \% & 6.14 & 8.57 & 9.47 \\
\hline
\end{tabular}

**= Significant at the $1 \%$ probability level; CGR=Callus Growth Rate; RFMG=Relative Fresh Mass Growth; RGR=Relative Growth Rate

Table 3: Analysis of variance for mature embryos callus characters under stress conditions

\begin{tabular}{lccccccc}
\hline \multirow{2}{*}{ S.O.V. } & \multirow{2}{*}{ df } & \multicolumn{9}{c}{ Mean Squares } \\
\cline { 3 - 8 } & & CGR & RFMG & RGR & CWC & PCC & PC \\
\hline Genotype (G) & 19 & $0.121^{* *}$ & $0.071^{* *}$ & $0.004^{* *}$ & $140.131^{* *}$ & $0.055^{* *}$ & $0.684^{* *}$ \\
Drought (D) & 1 & $1.126^{* *}$ & $0.421^{* *}$ & $0.014^{* *}$ & $3190.971^{* *}$ & $5.607^{* *}$ & $11.102^{* *}$ \\
D $\times$ G & 19 & $0.010^{\text {ns }}$ & $0.018^{\text {ns }}$ & $0.002^{\text {ns }}$ & $81.198^{* *}$ & $0.013^{\text {ns }}$ & $0.242^{* *}$ \\
Error & 80 & 0.011 & 0.011 & 0.001 & 3.811 & 0.015 & 0.004 \\
\hline CV \% & - & 7.92 & 9.77 & 3.37 & 2.29 & 8.87 & 3.87 \\
\hline ns & & & & & & &
\end{tabular}

ns and $* *=$ Non-significant and significant at the $1 \%$ probability level, respectively; CGR=Callus Growth Rate; RFMG=Relative Fresh Mass Growth; RGR=Relative Growth Rate; CWC $=$ Callus Water Content; PCC $=$ Percentage of Callus Chlorosis; $\mathrm{PC}=$ Proline Content. 
Table 4: Mean comparison of in vitro indicators of drought tolerance under stress (15\% PEG) and non-stress $(0 \%$ PEG) using mature embryo culture

\begin{tabular}{ccccccc}
\hline Drought (\%) & CGR & RFMG & RGR & CWC & PCC & PC \\
\hline 0 & $1.4385^{\mathrm{a}}$ & $0.3882^{\mathrm{a}}$ & $0.0185^{\mathrm{a}}$ & $90.3970^{\mathrm{a}}$ & $15.6033^{\mathrm{a}}$ & $2.0909^{\mathrm{a}}$ \\
15 & $1.2448^{\mathrm{b}}$ & $0.1534^{\mathrm{b}}$ & $-0.0027^{\mathrm{b}}$ & $80.0836^{\mathrm{b}}$ & $42.7461^{\mathrm{b}}$ & $4.3008^{\mathrm{b}}$ \\
\hline
\end{tabular}

Means, in each column, followed by at least one letter in common are not significantly different at the $1 \%$ probability level. CGR=Callus Growth Rate; RFMG=Relative Fresh Mass Growth; RGR=Relative Growth Rate; $\mathrm{CWC}=$ Callus Water Content; $\mathrm{PCC}=$ Percentage of Callus Chlorosis; PC $=$ Proline Content.

\subsection{Screening drought tolerance indicators and drought tolerant genotypes}

\subsubsection{In vitro indicators of drought tolerance}

Callus growth index (CGI) exhibited remarkable differences among the genotypes in the means of increasing value of selected calli. Genotypes number 2, 10, 18, 19 and 13 showed the highest callus increasing value, respectively (Table 5 ). The highest amount of relative tolerance (Rt \%) in the induced drought stress condition was attributed to genotypes number 5, 11, 3, 9 and 14, respectively.
The lowest amount of reduction percentage (RP) from 0.0 to $15 \%$ PEG belonged to genotypes number 17, 7, 3, 4 and 5 and the highest amount of RP was shown by genotype number 20 (Table 5). With regard to callus (resulted from mature embryos) increasing value, percentage of relative tolerance (Rt \%) and the amount of reduction percentage (RP) genotypes number 2 and 5 were selected as the most drought tolerant at in vitro conditions.

Table 5: Ranks (R), ranks mean $(\overline{\mathrm{R}})$, standard deviation of ranks (SDR), rank sum (RS) of in vitro indicators of drought tolerance using mature embryo culture and integrated selection index (ISI) of investigated genotypes

\begin{tabular}{ccccccccccccc}
\hline Genotype & CGR & R & RFWG & R & RGR & R & CGI & R & Rt \% & R & RP & R \\
\hline 1 & 1.29 & 14 & 0.775 & 2 & 0.035 & 2 & 0.270 & 6 & 48.64 & 16 & 7.75 & 12 \\
2 & 1.40 & 7 & 1.234 & 1 & 0.048 & 1 & 0.536 & 1 & 41.56 & 19 & 11.08 & 19 \\
3 & 1.22 & 18 & -0.054 & 16 & -0.004 & 14 & -0.072 & 15 & 81.96 & 3 & 2.00 & 3 \\
4 & 1.01 & 20 & -0.097 & 18 & -0.007 & 17 & -0.114 & 19 & 74.13 & 6 & 2.15 & 4 \\
5 & 1.05 & 19 & 0.099 & 13 & 0.001 & 13 & -0.005 & 13 & 92.73 & 1 & 3.00 & 5 \\
6 & 1.25 & 16 & -0.064 & 17 & -0.005 & 15 & -0.078 & 17 & 67.11 & 9 & 8.29 & 14 \\
7 & 1.28 & 15 & 0.687 & 3 & 0.030 & 3 & 0.218 & 7 & 35.98 & 20 & 1.67 & 2 \\
8 & 1.51 & 3 & -0.113 & 19 & -0.012 & 18 & -0.127 & 18 & 48.53 & 17 & 6.15 & 11 \\
9 & 1.40 & 6 & 0.132 & 12 & 0.006 & 12 & 0.059 & 10 & 78.12 & 4 & 8.83 & 17 \\
10 & 1.37 & 12 & 0.601 & 4 & 0.029 & 4 & 0.338 & 2 & 56.85 & 13 & 4.84 & 9 \\
11 & 1.40 & 8 & 0.076 & 14 & -0.024 & 20 & -0.024 & 14 & 87.64 & 2 & 3.70 & 6 \\
12 & 1.43 & 5 & 0.151 & 11 & 0.008 & 10 & 0.003 & 12 & 63.87 & 10 & 4.32 & 8 \\
13 & 1.55 & 1 & 0.533 & 6 & 0.023 & 6 & 0.278 & 5 & 59.72 & 11 & 5.30 & 10 \\
14 & 1.38 & 11 & 0.165 & 10 & 0.007 & 11 & 0.035 & 11 & 76.36 & 5 & 8.47 & 16 \\
15 & 1.54 & 2 & 0.307 & 9 & 0.014 & 9 & 0.134 & 8 & 72.29 & 7 & 8.15 & 13 \\
16 & 1.38 & 10 & 0.374 & 8 & 0.018 & 8 & 0.096 & 9 & 67.22 & 8 & 8.40 & 15 \\
17 & 1.39 & 9 & -0.223 & 20 & -0.020 & 19 & -0.231 & 20 & 49.76 & 15 & 0.50 & 1 \\
18 & 1.44 & 4 & 0.557 & 5 & 0.025 & 5 & 0.293 & 3 & 57.73 & 12 & 4.22 & 7 \\
19 & 1.32 & 13 & 0.401 & 7 & 0.019 & 7 & 0.280 & 4 & 50.30 & 14 & 9.82 & 18 \\
20 & 1.25 & 17 & -0.030 & 15 & -0.007 & 16 & -0.075 & 16 & 48.24 & 18 & 14.54 & 20 \\
\hline
\end{tabular}


Table 5: Continued

\begin{tabular}{cccccccccccc}
\hline Genotype & CWC $\%$ & R & PCC $\%$ & R & PC & R & ISI & R & $\overline{\mathbf{R}}$ & SDR & RS \\
\hline 1 & 87.04 & 6 & 19.58 & 2 & 2.75 & 13 & 4.92 & 2 & 7.5 & 5.68 & 13.18 \\
2 & 89.07 & 1 & 19.11 & 1 & 6.93 & 1 & 11.30 & 1 & 5.2 & 7.51 & 12.71 \\
3 & 86.47 & 9 & 32.52 & 17 & 2.64 & 14 & -3.91 & 17 & 12.6 & 5.64 & 18.24 \\
4 & 88.01 & 3 & 39.87 & 19 & 1.53 & 18 & -5.90 & 19 & 14.3 & 6.96 & 21.26 \\
5 & 85.60 & 13 & 20.00 & 3 & 3.64 & 7 & -1.43 & 13 & 10.0 & 5.68 & 15.68 \\
6 & 85.22 & 17 & 30.07 & 12 & 4.10 & 5 & -2.01 & 14 & 13.6 & 3.95 & 17.55 \\
7 & 85.80 & 12 & 24.32 & 4 & 3.90 & 6 & 3.75 & 4 & 7.6 & 6.06 & 13.66 \\
8 & 87.24 & 4 & 33.85 & 18 & 4.43 & 3 & -2.02 & 15 & 12.6 & 6.79 & 19.39 \\
9 & 85.45 & 15 & 30.78 & 13 & 2.64 & 15 & -1.07 & 11 & 11.5 & 4.03 & 15.53 \\
10 & 86.47 & 10 & 26.31 & 6 & 4.70 & 2 & 4.35 & 3 & 6.5 & 4.17 & 10.67 \\
11 & 86.70 & 8 & 28.33 & 10 & 2.99 & 9 & -3.15 & 16 & 10.7 & 5.29 & 15.99 \\
12 & 86.42 & 11 & 31.82 & 16 & 2.81 & 11 & -1.20 & 12 & 10.6 & 2.84 & 13.44 \\
13 & 85.10 & 18 & 31.66 & 14 & 2.80 & 12 & 2.08 & 7 & 9.0 & 4.97 & 13.97 \\
14 & 85.49 & 14 & 26.93 & 9 & 2.56 & 16 & -0.65 & 10 & 11.3 & 3.33 & 14.63 \\
15 & 85.22 & 16 & 26.66 & 8 & 3.21 & 8 & 1.25 & 9 & 8.9 & 3.67 & 12.57 \\
16 & 87.09 & 5 & 26.40 & 7 & 4.13 & 4 & 1.99 & 8 & 8.2 & 2.97 & 11.17 \\
17 & 69.58 & 20 & 49.46 & 20 & 1.46 & 19 & -9.74 & 20 & 16.3 & 6.43 & 22.73 \\
18 & 88.91 & 2 & 25.14 & 5 & 2.39 & 17 & 3.04 & 5 & 6.5 & 4.58 & 11.08 \\
19 & 86.77 & 7 & 28.75 & 11 & 2.89 & 10 & 2.43 & 6 & 9.7 & 4.32 & 14.02 \\
20 & 73.74 & 19 & 31.79 & 15 & 1.32 & 20 & -4.03 & 18 & 17.4 & 1.90 & 19.30 \\
\hline
\end{tabular}

CGR=Callus Growth Rate; RFMG=Relative Fresh Mass Growth; RGR=Relative Growth Rate; CGI=Callus Growth Index; Rt \%=Relative tolerance; $\mathrm{RP}=$ Reduction Percentage; $\mathrm{CWC}=\mathrm{Callus}$ Water Content; $\mathrm{PCC}=$ Percentage of Callus Chlorosis; $\mathrm{PC}=$ Proline Content; ISI=Integrated Selection Index.

\subsubsection{Biplot analysis method}

The relationships among different physiological indices of drought tolerance are graphically displayed in a biplot of $\mathrm{PCA}_{1}$ and $\mathrm{PCA}_{2}$ (Figure 1). The $\mathrm{PCA}_{1}$ and $\mathrm{PCA}_{2}$ axes which justify $71.46 \%$ of total variation, mainly distinguish the indices in different groups. CGR groups RP and we refer to group $1=\mathrm{G} 1$ indices which introduce genotypes number 13,15 and 16 as mild drought tolerant. The PCs axes separated ISI, CGI, RFMG, RGR, $\mathrm{PC}$ and $\mathrm{CWC}$ in a single group (G2) that identify genotype number $2,1,7,10$ and 18 as the most drought tolerant. PCC and Rt \% were separated as groups 3 (G3) and 4 (G4) that distinguished genotypes $17,20,8$ and $3,4,5,11$ as drought susceptible genotypes, respectively (Figure 1).

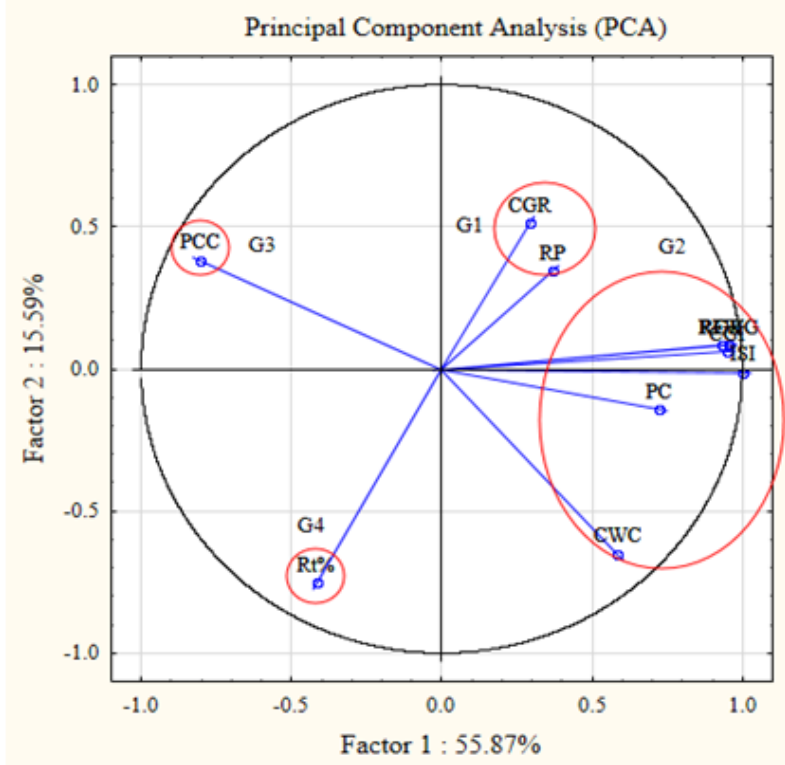

Figure 1: Biplot analysis of in vitro indicators of drought tolerance using mature embryo culture 


\subsubsection{Ranking method}

In consideration to all indices, genotypes number 10, 18, 16, 15 and 2 exhibited the lowest RS respectively; hence they were identified as the most drought tolerant genotypes, while genotypes number $17,4,8$, and 20 as the most sensitive (Table 5).

\section{DISCUSSION}

Observation of highly significant differences among the genotypes for CGR, RFMG and RGR indicated the presence of genetic variability, different responses of genotypes to callus induction and possible selection of callus induction in bread wheat genotypes at in vitro level using mature embryos of wheat. Abdulaziz et al. (2002) studied the callus to varying degree of polyethylene glycol (PEG)-induced water stress. They studied callus growth, water content and proline accumulation, and their results revealed that increasing water stress induced by increasing concentration of PEG caused a progressive reduction in callus fresh mass. In the present work, the sharp increase in proline content might theoretically, attribute to the genes for synthesis and degradation of proline which are up-regulated strongly under drought stress. It might be an adaptation to the purpose of which is to overcome the stress condition and it could supply energy for growth and survival and thereby help the plant to tolerate stress (Sankar et al., 2007). Abdelsamad et al. (2007) reported that significant differences of genetic responses were observed for the four wheat genotypes at 10 and $20 \%$ PEG for callus induction, callus fresh mass, growth index, relative water content and relative tolerance percentage.

Principal component analysis (PCA), based on the rank correlation matrix was used to better understand the relationships, similarities and dissimilarities among the in vitro indicators of drought tolerance. One interesting interpretation of biplot is that the cosine of the angle between the vectors of two indices approximates the correlation coefficient between them. The cosine of the angles does not precisely translate into correlation coefficients, since the biplot does not explain all of the variation in a data set. Nevertheless, the angles are informative enough to allow a whole picture about the interrelationships among the in vitro indices (Yan and Kang, 2003). This procedure was also employed in chickpea (Cicer arietinum L.) (Zali et al., 2011) for clustering stability statistics, in barley (Khalili et al., 2013) and in bread wheat (Farshadfar et al., 2012; Farshadfar et al., 2013a,b) for screening selection criteria of drought tolerance.

The estimates of different indicators of drought tolerance indicated that the identification of drought-tolerant genotypes based on a single criterion was contradictory. Therefore, the ranking method can be used to have an overall judgment. In this method to determine the most desirable drought tolerant genotype according to the all indices mean rank, standard deviation of ranks and rank sum (RS) of all criteria is calculated. Results of the ranking method showed that genotypes number 10, 18, 16, 15 and 2 exhibited the lowest RS respectively; hence they were identified as the most drought tolerant genotypes, while genotypes number $17,4,8$, and 20 as the most sensitive. These results are in agreement with the results of our new index (ISI). Therefore they can be used as parental materials for crossing, genetic analysis, mapping quantitative trait loci (QTLs) and marker assisted selection. The same procedures have been used for screening quantitative indicators of drought tolerance in barely (Khalili et al., 2013), in wheat (Mohammadi et al., 2011) and in bread wheat (Farshadfar, 2012; Farshadfar and Elyasi, 2012; Farshadfar et al., 2012; Farshadfar et al., 2013a,b). 


\section{CONCLUSION}

Screening drought tolerant genotypes and indicators of drought tolerance using mean rank, standard deviation of ranks and biplot analysis under in vitro condition, which led to save time and money, discriminated genotypes "WC-4530", "WC-4931" and "WC-47399" as the most drought tolerant. These genotypes should be tested in a field trial and then looking for the association or correlation between in vitro and in vivo conditions. Therefore, these genotypes can be recommended to be used as parents for genetic analysis, gene mapping and improvement of drought tolerance in bread wheat when the results of in vitro and in vivo conditions are certified.

\section{REFERENCES}

Abdelsamad, A., El-Sayed, O.E., \& Ibrahim, F. (2007). Development of drought tolerance haploid wheat using biochemical genetic markers on in vitro culture. Journal of Applied Sciences Research, 3(11), 1589-1599.

Abdulaziz, M., \& Al-Bahrany, A.M. (2002). Callus growth and praline accumulation in response to polyethyleneglycol-induced osmotic stress in rice (Oryza sativa L.). Journal of Biological Sciences, 5(12), 1294-1296

Amiri, R., Bahraminejad, S., \& Jalali-Honarmand, S. (2013). Effect of terminal drought stress on grain yield and some morphological traits in 80 bread wheat genotypes. International Journal of Agriculture and Crop Sciences, 5(10), 1145-1153.

Anjum, S.A., Xie, X.Y., Wang, L.C., Saleem, M.F., Man, C., \& Lei, W. (2011). Morphological, physiological and biochemical responses of plants to drought stress. African Journal of Agricultural Research, 6(9), 2026-2032.

Araus, J.L., Salfer, M.P., Royo, C., \& Serett, M.D. (2008). Breeding for yield potential and stress adaptation in cereals. Critical Reviews in Plant Sciences, 27(6), 377-412. Doi: $10.1080 / 07352680802467736$

Bajji, M., Bertin, P., Lutts, S., \& Kinet, J.M. (2004). Evaluation of drought resistance? Related traits in durum wheat somaclonal lines selected in vitro. Australian Journal of Experimental Agriculture, 44, 27-35. Doi: 10.1071/EA02199

Bayoumi, T.Y., Eid, M.H., \& Metwali, E.M. (2008). Application of physiological and biochemical indices as a screening technique for drought tolerance in wheat genotypes. African Journal of Biotechnology, 7(14), 2341-2352.

Binott, J.J., Songa, J.M., Ininda, J., Njagi, E.M., \& Machuka, J. (2009). Plant regeneration from immature embryos of Kenyan maize inbred lines and their respective single cross hybrids through somatic embryogenesis. African Journal of Biotechnology, 7(8), 981-987.

Birsin, M.A., \& Ozgen, M. (2004). A comparison of callus induction and plant regeneration from different embryo explants of triticale (X Triticosecale Wittmack). Cellular and Molecular Biology Letters, 9, 353-361.

Chen, J.J., Yue, R.Q., Xu, H.X., \& Chen, X.J. (2006). Study on plant regeneration of wheat mature embryos under endosperm supported culture. Agricultural Sciences in China, 5(8), 572-578. Doi: 10.1016/S1671-2927(06)60094-1

Compton, M.E. (1994). Statistical methods suitable for the analysis of plant tissue culture data. Plant Cell, Tissue and Organ Culture, 37, 217-242.

Errabi, T., Gandonou, C.B., Essalmani, M., Abrini, J., Idaomar, M., \& Skali-Senhagi, N. (2006). Growth, proline and ion accumulation in sugarcane callus caltures under drought-induced osmotic stress and its subsequent relief. African Journal of Biotechnology, 5(16), 1488-1493.

Farshadfar, E. (2012). Application of integrated selection index and rank sum for screening drought tolerant genotypes in bread wheat. International Journal of Agriculture and Crop Sciences, 4-6, 325332.

Farshadfar, E., \& Elyasi P. (2012). Screening quantitative indicators of drought tolerance in bread wheat (Triticum aestivum L.) landraces. European Journal of Experimental Biology, 2(3), 577-584.

Farshadfar E., Elyasi P., Aghaee M. 2012. In Vitro selection for drought tolerance in common wheat (Triticum aestivum L) genotypes by mature embryo culture. American Journal of Scientific Research, $48,102-115$

Farshadfar, E., Poursiahbidi, M.M., Safavi, S.M., \& Vosough, A. (2013a). Screening of Drought Tolerant Genotypes in Bread Wheat using a New

Acta agriculturae Slovenica, 107 - 2, september 2016 
Integrated Selection Index. Advanced Crop Science, 3(3), 237-246.

Farshadfar, E., Safavi, S.M., \& Vosough, A. (2013b). Chromosomal localization of the genes, controlling a new integrated selection index for improvement of drought tolerance in wheat. Advanced Crop Science, 3(2), 209-217.

Gawande, N.D., Mahurkar, D.G., Rathod, T.H., Jahagidar, S.W., \& Shinde, M. (2005). In vitro screening of wheat genotypes for drought tolerance. Annals of Plant Physiology, 19, 162-168.

Ghasemali, N., Soheil, Z., \& Mohammad, S.M. (2011). Study of effects late season drought stress in wheat cultivars using stress susceptibility, tolerance indices and canopy temperature depression (CTD). Advances in Environmental Biology, 5, 3929-3933.

Ilker, E., Tatar, Ö., Aykut Tonk, F., \& Tosun, M. (2011). Determination of tolerance level of some wheat genotypes to post-anthesis drought. Turkish Journal of Field Crops, 16(1), 59-63.

Khakwani, A.A., Dennett, M.D., \& Munir, M. (2011). Drought tolerance screening of wheat varieties by inducing water stress conditions. Songklanakarin Journal of Science and Technology, 33(2), 135-142.

Khalili, M., Pour Aboughadareh, A., \& Naghavi, M.R. (2013). Screening of drought tolerant cultivars in barley using morpho-physiological traits and Integrated Selection Index under water deficit stress condition. Advanced Crop Science, 3(7), 462-471.

Khan, S., Khan, J., Islam, N., \& Islam, M. (2011). Screening and evaluation of wheat germplasm for yield, drought and disease resistance under rainfed conditions of upland Baluchistan. Pakistan Journal of Botany, 43, 559-563.

Leilah, A.A., \& AL-Khateeb, S.A. (2005). Statistical analysis of wheat yield under drought conditions. Journal of Arid Environments, 61(3), 483-496. Doi: 10.1016/j.jaridenv.2004.10.011

Mahmood, I., Razzaq, A., Khan, Z., Hafiz, I.A., \& Kaleem, S. (2012). Evaluation of tissue culture responses of promising wheat (Triticum aestivum L.) cultivars and development of efficient regeneration system. Pakistan Journal of Botany, 44, 277-284.

Mohammadi, R., Sadeghzadeh, D., Armion, M., \& Amri, A. (2011). Evaluation of durum wheat experimental lines under different climate and water regime strategies. Crop and Pasture Science, 62(2), 137-151. Doi: 10.1071/CP10284
Murashige, T., \& Skooge, F. (1962). A revised medium for rapid growth and bioassays with tobacco tissue cultures. Plant Physiology, 15, 473-497. Doi: 10.1111/j.1399-3054.1962.tb08052.x

Pan, X.Y., Wang, Y.F., Wang, G.X., Cao, Q.D., \& Wang, J. (2002). Relationship between growth redundancy and size inequality in spring wheat populations mulched with clear plastic film. Acta Phytoecology Sinica, 26, 177-184.

Shah, M.M., Khalid, Q., Khan, U.W., Shah, S.A.H., Shah, S.H., Hassan, A., \& Pervez, A. (2009). Variation in genotypic responses and biochemical analysis of callus induction in cultivated wheat. Genetics and Molecular Research, 8(3), 783-793. Doi: 10.4238/vol8-3gmr513

Sankar, B., Jaleel, C., Manivannan, P., Kishorekuma, A., Somasundaram, R., \& Panneerselvan, R. (2007). Drought-induced biochemical modification and proline metabolism in Abelmoschus esculentus (L) Moench. Acta botanica Croatica, 66, 43-56.

Sorkheh, K., Shiran, B., Khodambshi, M., Rouhi, V., \& Ercisli, S. (2011). In vitro assay of native Iranian almond species (Prunus L. spp.) for drought tolerance. Plant Cell, Tissue and Organ Culture, 105, 395-404. Doi: 10.1007/s11240-010-9879-1

Vasil, I.K. (2003). The science and politics of plant biotechnology - a personal perspective. Nature Biotechnology, 21, 849-851. Doi: 10.1038/nbt0803-849

Yan, W., \& Kang, M.S. (2003). Biplot Analysis: A graphical Tool for Breeders, Geneticists and Agronomist, CRC Press, Boca Raton, FL. 313.

Yea, Y., Wang, G., Huang, Y., Zhu, Y., Meng, Q., Chen, X., Zhang, F., \& Cui, Z. (2011). Understanding physiological processes associated with yield-trait relationships in modern wheat varieties. Field Crops Research, 124, 316-322. Doi: 10.1016/j.fcr.2011.06.023

Zair, I., Chlyah, A., Sabounji, K., Titahsen, M., \& Chlyah, H. (2003). Salt tolerance improvement in some wheat cultivars after application of in vitro selection pressure. Plant Cell, Tissue and Organ Culture, 73, 237-244. Doi: 10.1023/A:1023014328638

Zali, H., Farshadfar, E., \& Sabaghpour S.H. (2011). Non-parametric analysis of phenotypic stability in chickpea (Cicer arietinum L.) genotypes in Iran. Crop Breeding Journal, 1(1), 85-96. 